\title{
Biodiversidade: o Brasil e o quadro internacional
}

\author{
MARCELODIAS VARELLA*
}

\section{Introdução}

O Brasil detém a maior variabilidade genética do mundo, sua flora é constituída por cerca de 55 mil espécies conhecidas ${ }^{1}$, além de inúmeras outras não catalogadas ou mesmo desconhecidas pela ciência biológica ${ }^{2}$, o que se deve principalmente a sua posição geográfica privilegiada, ao clima eumidade adequados e a inúmeros outros fatores bióticos e abióticos propícios. No entanto, esta diversidade genética nem sempre existiu, mas foi se constituindo com o passar dos séculos, por meio da migração de plantas e animais, através dos países e mesmo entre os continentes.

Ao analisar o material vivo existente hoje na grande maioria das regiões do planeta, percebem-se traços de sua passagem anterior por diversos outros lugares. Nos Estados Unidos, por exemplo, onde existem aproximadamente mil variedades cultivadas, 99,7\% não são originárias deste país, com exceção apenas das alcachofras-de-jerusalém, das cerejeiras silvestres e do girassol ${ }^{3}$.

As regiões equatoriais, mais quentes, detêm maior diversidade biológica e são conhecidas como Centros de Vavilov ${ }^{4}$, que são o Mediterrâneo, Oriente Próximo,Afeganistão, Indo-Birmânia, Malásia-Java, China, Guatemala, México, Andes Peruanos eEtiópia. Por serem regiões de maior biodiversidade, apresentamse também como os maiores centros de difusão de espécies vivas para os demais países. Nestas localidades, percebe-se que a variabilidade biológica é muito superior mesmo às regiões mais próximas. Assim, a região Amazônica, por exemplo, possui um número de espécies vivas oito vezes maior que a Bacia do Mississipi ou dez vezes superior ao total de espécies da Europa.

Rev. Bras. Polít. Int. 40 (1): 123-141 [1997].

* Diplomata. 
Somente nos últimos anos iniciou-se a regulamentação jurídica de toda esta biodiversidade, com a adoção de medidas concretas para a criação de mecanismos de segurança biológica, de proteção intelectual de plantas e microrganismos e mesmo de proteção ao acesso dos recursos genéticos brasileiros.

Nesse estudo, pretende-se apontar os principais instrumentos jurídicos para a regulamentação da biodiversidade, em vários de seus aspectos. Deste modo, em um primeiro momento serão tratados dispositivos legais que tratam da propriedade intelectual sobre seres vivos, como a nova lei de patentes e a nova lei de proteção de cultivares. Em seguida, a segurança biológica no tocante aos organismos geneticamente modificados, matéria conhecida como biossegurança e, por último, a matéria referente à proteção do acesso aos recursos genéticos brasileiros, que ainda está sem qualquer regulamentação, mas que devido a sua importância não poderia ser excluída desta análise.

Como os aspectos jurídicos estão estreitamente ligados a questões políticas e econômicas, serão estudados os principais fatores internacionais que conduziram o legislador brasileiro a adotar tais normas. Como se trata de um artigo abrangente, com assuntos distintos, os temas serão tratados de forma sucinta com o estudo apenas de alguns de seus caracteres principais.

\section{Agenda 21}

AAgenda 21 foi um dos acordos realizados quando da Conferência das Nações Unidas sobre Meio Ambiente e Desenvolvimento, realizada no Rio de Janeiro, em 1992, um dos maiores, senão o mais significativo evento diplomático deste século, com a participação de todos os Estados de maior importância, além de centenas de Organizações não-governamentais(ONGs) de diversos setores do conhecimento e com interesses vários. A Agenda 21 possui 40 capítulos, é um compromisso extenso, com centenas de disposições sobre políticas de cooperação internacional a serem adotadas, com vistas à melhoria da qualidade de vida das populações de todo o mundo e na preservação e mesmo recuperação do meio ambiente. Como os mecanismos para tal desenvolvimento exigem grandes recursos financeiros, nem todos os países ratificaram de pronto a convenção, com destaque para os Estados Unidos, um dos últimos a se tornar parte do acordo. Atualmente, mais de 130 países já o ratificaram, o que lhe dá amplitude suficiente para ter eficácia global.

Desde 1992, três conferências foram realizadas para a regulamentação dos dispositivos firmados, nos quais se discutem as principais medidas tomadas neste período e fixam-se novos objetivos, a serem avaliados pelos grupos de 
discussão, coordenados pela Organização das Nações Unidas e implementados nos mais diversos países. Infelizmente, cinco anos após a assinatura da Agenda 21 , poucos foram os resultados atingidos. Embora algunsdiplomas legaisimportantes tenham sido assinados, percebe-se que os índices de destruição ao meio ambiente continuam, com a melhoria em alguns poucos aspectos, e principalmente, quase nada foi feito para a diminuição da pobreza dos países periféricos. Aregulamentação internacional ainda é pequena e os acordos para cooperação Norte-Sul para erradicação da pobreza continuam praticamente nos mesmos padrões de antes da Convenção. Nas conferências posteriores, muito se discutiu, mas poucas medidas concretas foram adotadas. Enquanto isto, o direito positivo internacional permanece com uma das mais importantes convenções internacionais já firmadas sem regulamentação, com pouca eficácia.

\section{Direito positivo nacional}

\section{a) Biossegurança}

Biossegurança é o conjunto de técnicas e princípios utilizados para a diminuição dos riscos biológicos, para a proteção do meio ambiente, da saúde pública e da vida humana. Geralmente está relacionada com a manipulação, uso, criação, transporte e outras atividades que envolvam organismos geneticamente modificados (OGM). A legislação sobre a matéria também é recente e já fora prevista pela Agenda 21, em 1992, no capítulo 16, que cuida do "manejo ambientalmente saudável da biotecnologia”. Em todo o mundo, cerca de 50 países já legislaram sobre o tema, com dispositivos que variam conforme os princípios norteantes de cada norma.

Desse modo, enquanto alguns países privilegiam apenas a segurança biológica, avaliada pelo cumprimento das normas internacionais de biossegurança, como a legislação da Comunidade Européia, outros colocam em relevo a opinião pública sobre a realização das experiências, como na Nova Zelândia ou Suiça. No primeiro caso, para quehaja a emissão deum organismo geneticamente modificado no meio ambiente, o órgão público verifica a segurança do mesmo; já no segundo, além da ausência de riscos biológicos, avalia-se a opinião da coletividade sobre aquelas pesquisas.

Emâmbito internacional, destaca-se a legislação da Comunidade Européia e dos Estados Unidos. Na Europa, os principais diplomas legais são as Diretivas do Conselho Europeu n ${ }^{\circ} .219$, de 23 de abril de 1990 (90/219/EEC), que tratam do uso contido de microrganismos geneticamente modificados; a Diretiva $n^{\circ} .220$, de 
03 de abril de 1990 (90/220/EEC), que cuida da liberação voluntária de organismos geneticamente modificados no meio ambiente; e a Diretiva da Comissão das Comunidades Européias n ${ }^{\circ}$. 51, de 7 de novembro de 1994 (94/51/EEC), e a Decisão da Comissão das Comunidades Européias n ${ }^{\circ} .730$, de 12 de novembro de 1994 (94/730/EC), que cuidam do estabelecimento de procedimentos mais simplificados para a liberação intencional de plantas geneticamente modificadas no meio ambiente.

Os Estados Unidos possuem uma das mais complexas legislações sobre biossegurança do mundo. Várias instituições são encarregadas de verificar a segurança biológica dos produtos novos. A fiscalização abrange diversas fases, analisando os processos empregados e os produtos obtidos, as repercussões no meio ambiente etc. Os principais organismos competentes para o trato com a matéria sãoaAdministraçãodeAlimentose Drogas (Foodand DrugAdministration - FDA), o Instituto Nacional de Saúde (National Institute of Health - NIH), o Departamento de Agricultura (United States Department of Agriculture USDA) e a Agência de Proteção ao Meio Ambiente (Environmental Protection Agency - EPA).

A Agenda 21 trata da biossegurança em diversas partes, com destaque para os capítulos 8,15,16 e 19, na medida em que propõe mecanismos de fomento ao manejo de novas tecnologias biológicas, com o objetivo de promover bons impactos das novas técnicas no meio ambiente. Importante ressaltar que é característica comum de todos os textos mencionados a afirmação da biotecnologia como um instrumento para o progresso de toda a humanidade, ressaltando-se apenas a necessidade de aplicar um controle correto de seu uso para a manutenção de um meio ambiente saudável.

A Conferência das Partes, em Jakarta, na sua decisão II/5 também veio fixar regras relativas à biossegurança, a partir da criação de um grupo de trabalho ad hoc no qual se ressaltou a importância de se implementar um Guia de Condutas Técnicas de Segurança em Biotecnologia, pela UNEP, e da fixação de mecanismos para a troca de informações entre os órgãos responsáveis etc. O objetivo dos guias de boa conduta e das convenções internacionais é promover a homogeneização legislativa internacional para melhor proteção do meio ambiente e da saúde humana.

No Brasil, a matéria é regulada pela Lein ${ }^{\circ}$.8.974, de 05 de janeiro de 1995, e pelo Decreto ${ }^{\circ}$. 1.572, de 20 de dezembro do mesmo ano. A legislação cria a Comissão Técnica Nacional de Biossegurança (CTNBio), formada por 18 profissionais, com representantes do Ministério da Saúde; Ciência e Tecnologia; Agricultura; Meio Ambiente, Recursos Hídricos e da Amazônia Legal, além de 
representantes dos consumidores, dos trabalhadores, do setor empresarial e da comunidade científica, considerados como agentes honoríficos. Infelizmenteestes profissionais não são remunerados.

A partir da nova lei, toda e qualquer atividade que envolva experimentos relacionados com organismos geneticamente modificados deve ser aprovada pela CTNBio, que exigirá o cumprimento das normas internacionais de segurança biológica. Alei prevêtambém mecanismos de participação popular na tomada de decisões com relação à liberação de organismos no meio ambiente, dispositivos avançados com caracteres até então inéditos no direito administrativo nacional, além de diversos ilícitos penais, como em relação à manipulação genética de células germinais humanas, pesquisas genéticas não autorizadas etc.

Antes de tudo, porém, é importante saber o que significa a expressão “engenharia genética”, que pode ser definida como a atividade de manipulação de moléculas deácido desoxiribunucleico(ADN)edeácido ribonucleicorecombinantes (ARN).ADN ou DNA, como é mais conhecido no meio científico internacional, significa o material genético de um ser vivo, seja ele um simples microrganismo, seja ele o homem. Este material genético contém as informações determinantes dos caracteres hereditários transmissíveis à descendência.É o material genético que informa à prole quais serão as suas características, como a cor dos olhos, dos cabelos, o sexo, a formação do corpo etc. No caso do homem, o material genético se encontra em 46 pares de cromossomos.

ACTNBiotem diversas atribuições relacionadas com otrato de organismos geneticamente modificados (OGMs), com competência para interagir com as entidades que desenvolvam pesquisas relacionadas com engenharia genética, propor o Código de Manipulações Genéticas, além de fixar normas instituindo técnicas de segurança na manipulação de seres vivos, entre outras funções. Também prevê a criação das Comissões Internas de Biossegurança (CIBIO), que devem existir em cada instituição, para o acompanhamento mais próximo das medidas preventivas e mesmo para a tomada de medidas de urgência nos casos de acidentes biológicos.

Fica proibida a manipulação genética por pessoas físicas, o que tem sido muito discutido tanto pela doutrina nacional, como pela comunidade científica como um todo, face à liberdade de escolha de profissão, garantia individual erigida a princípio constitucional na Carta de 1988. A tal argumento alia-se a exigência da lei 8.974 de um profissional responsável pelas atividades desenvolvidas, noâmbito da empresa, denominado Pesquisador Principal, com funções e responsabilidades definidas em lei. O maior argumento pela possibilidade da realização de pesquisas por pessoas físicas é justo pelo fato da exigência legal de uma pessoa responsável 
por toda a atividade científica, o Pesquisador Principal. Se a lei já responsabiliza uma pessoa individual no caso de acidentes, não haveria motivos para a proibição do desenvolvimento destas pesquisas sob a responsabilidade de uma única pessoa, que da mesma forma poderia ser fiscalizada e mesmo punida pelas autoridades competentes.

A aplicação destes dispositivos está apenas começando, pois a CTNBio somente foi criada há poucos meses. De qualquer forma, a legislação brasileira segue os padrões estabelecidos internacionalmente, sendo uma das mais avançadas legislações mundiais, na medida em que prevê instâncias de participação de diversos segmentos da sociedade, com representantes tanto da comunidade científica, como das empresas, dos trabalhadores e dos consumidores, com a possibilidade de manifestação popular antes da autorização relativa à liberação de organismos geneticamente modificados no meio ambiente. A lei debiossegurança também se destaca na medida em que prevê novos tipos penais, com sanções sobre as empresas e pessoas físicas responsáveis por colocar em perigo de dano a sociedade como um todo, indo além das previsões internacionais, como o guia de boas condutas da UNEP. A própria presença de uma legislação neste sentido já constitui em grande avanço do ordenamento jurídico para a proteção do meio ambiente, da saúde pública e da vida.

\section{b) Propriedade intelectual e biodiversidade}

\section{b.1. Patentes}

Propriedade, de acordo com o direito civil brasileiro, é o direito de usar, gozar, dispor e fruir de uma determinada coisa; não é uma relação entre a pessoa e a coisa, até porque não existe relação jurídica entre pessoas e objetos; a propriedade é uma relação entre o titular da proteção e toda a sociedade. O ordenamento jurídico garante um direito ao proprietário e uma obrigação de não fazer de toda a sociedade-por isso se chama direito real, que vem de res (coisa) - algo oponível erga omnes (contra todos).

Diz-sepropriedadeintelectual, pois se trata de bens incorpóreos, imateriais, fruto do intelecto humano, que se opõem aos bens corpóreos, materiais. Os bens incorpóreos não podem ser tocados com as mãos, vistos com os olhos, mas apenas tangidos com a mente.

Não se protegem idéias em si, mas a expressão destas idéias, a materialização das mesmas. Por exemplo, não se patenteia a idéia de um livro, mas 
sim o conjunto de palavras e expressões materializado em um papel ou em outro instrumento de comunicação. Não se patenteia a idéia de construir um carro, mas o conjunto de cálculos, desenhos, gráficos e estruturas materializados na tela de um computador ou em um projeto escrito, concretizado, expresso.

Em nível internacional, a legislação de propriedade intelectual ganha relevo com a Convenção de Paris, em 1883. O Brasil foi o quarto país do mundo a se tornar signatário desta Convenção; logo, há mais de cem anos que o ordenamento jurídico brasileiro possui instrumentos patentários. Desde o seu início, o Brasil admitiu a proteção intelectual de produtos e processos farmacêuticos, o que foi suspenso mais tarde em 1945 com relação aos processos durante o Governo de Getúlio Vargas e, em 1969, com relação aos produtos.

A legislação perdurou a mesma até que em 1985 o Brasil foi incluído na lista dos países a serem investigados como "maus parceiros comerciais" dos Estados Unidos, sob a “acusação” de ausência de mecanismos “adequados” de propriedade intelectual, principalmente no tocante à indústria de informática. Em 1988, com a publicação da Lei Abrangente de Comércio e Competitividade, a Super 301, e com as reclamações da Associação das Indústrias Farmacêuticas (Pharmaceutical Manufactures Association - PMA) perante o Representante do Comércio dos Estados Unidos, as sanções foram aplicadas efetivamente. Os prejuízos causados foram superiores a US $\$ 250$ milhões, quando a previsão oficial era de US\$ 39 milhões. Interessante que o Brasil foi o único país efetivamente punido, o que se deve ao fato de ser o sétimo maior consumidor mundial de produtos farmacêuticos, posição que tende a crescer.

Em 1991, devido às novas pressões, o então Presidente Fernando Collor de Mello enviou mensagem ao Legislativo propondo o novo projeto que foi amplamente discutido ao longo de cinco anos, recebeu mais de 1000 emendas somente na sua primeira passagem pela Câmara dos Deputados, e foi aprovado apenas em 1996.

É necessária a compreensão dos aspectos internacionais do problema, pois no atual processo de globalização pode-se identificar a imposição de forças contrárias provenientes de diversos lados, que obrigam o recuo ou avanço dos direitos de soberania de cada país e, como o mercado interno está extremamente interligado com diversos fatores, a não ratificação do novo acordo poderia trazer sanções comerciais ao Brasil, principalmente oriundas dos Estados Unidos.

Nota-se que nos últimos anos, o Brasil foi colocado nas listas de investigações sobre práticas desleais de comércio, ao lado apenas de China e Cuba, sendo que, após a conclusão dos estudos, indicou-se que destes três países, apenas o Brasil mantinha práticas desleais, em destaque com relação à 
propriedade intelectual, o que gerou a sobretaxação dos produtos brasileiros exportados para os Estados Unidos na ordem de 100\% ad valorem, em 20 de outubro de 1988, acarretando prejuízos de mais de US\$250 milhões ${ }^{5}$. Caso uma nova legislação patentária não fosse aprovada após a ratificação da Rodada Uruguai, as sanções estimadas poderiam chegar a US\$1,8 bilhão, principalmente sobre o setor de suco de laranja, eletroeletrônicos, aço e calçados, que empregam milhares de pessoas ${ }^{6}$.

Percebe-se, contudo, que o mercado de produtos farmacêuticos no Brasil há quase vinte anos vem sendo desnacionalizado e, no cenário atual, as grandes empresas estrangeiras dominam o mercado interno. Cerca de $73 \%$ dos produtos comercializados são de grandes indústrias transnacionais, ficando as empresas nacionais com a fabricação de medicamentos secundários, com menor expressão nas vendas.

“Mas, então por que o Brasil foi o único país a sofrer retaliações?” Isto ocorreu pelo fato de que politicamente o Brasil representa o mais importante país do Terceiro Mundo e no setor farmacêutico tem uma importante posição no cenário mundial. Como lembra o diplomata Paulo Roberto de Almeida $^{7}$, não ficaria bem para os Estados Unidos ter um país tão importante politicamente e tão "rebelde" aos interesses norte-americanos neste setor sem sofrer retaliações, o que seria um "péssimo exemplo para os demais".

Podemos dizer que as medidas sofridas foram um exemplo que o governo dos Estados Unidos quis demonstrar, o que nos traz profunda indignação.

Nesse sentido se pronunciou o embaixador brasileiro junto ao GATT, em setembro de 1988, Paulo Nogueira Batista ${ }^{8}$ :

"Quando as maiores multinacionais entraram no Brasil, no setor farmacêutico, a decisão de excluir produtos farmacêuticos de patenteamento já estava em vigor. É improvável que os danos às multinacionais possam ser relevantes. A maior parte do mercado, $80 \%$ ou mais, pertence às multinacionais, sendo que disso $35 \%$ correspondem ao faturamento das empresas norte-americanas. Os restantes $20 \%$ da participação brasileira estão em mãos de empresas que fabricam medicamentos populares, feitos localmente com ervas. Portanto, patentes não são necessárias. Nenhum caso substantivo foi apresentado, no Brasil ou em Washington, contra a infração na indústria farmacêutica ... Além de não reconhecer que o governo norte-americano tem qualquer autoridade moral para fazer julgamentos sobre o tema, deixe-me recordar aos colegas que o único tipo de familiaridade que o Brasil teve com a pirataria foi na condição de vítima. Assim como a maioria de nossos 
vizinhos latino-americanos, desde o início do período colonial temos sido constantemente saqueados (plundered and ransacked) por notáveis perpetradores dessa segunda ou terceira mais antiga profissão, pessoas cujos nomes são Drake, Cavendish, Fenton, nomes que, aliás, não são portugueses ou espanhóis.”

Com relaçãoà biodiversidade, existem duas formas de proteção intelectual admitidas no direito brasileiro: a proteção por patentes e proteção de cultivares. Estas modalidades de proteção não se confundem, tendo traços característicos próprios com grandes repercussões práticas sobre o setor produtivo.

A legislação de patentes é tratada pela Lei $n^{\circ}$. 9.279, de 14 de maio de 1996, com vigência a partir de 15 de maio de 1997, portanto trata-se de uma norma jurídica recente.

As patentes são utilizadas apenas para a proteção de microrganismos transgênicos. Não se aceita patenteamento de plantas e animais ou partes de plantas e animais, como células destes organismos, ainda que de forma indireta, como quando inseridos em um processo industrial. Também é expressamente proibido o patenteamento de seqüências genéticas, como DNA (ácido desoxiribonucleico) ou RNA(ácido ribonucleico). Para se evitar quaisquer dúvidas com relação ao que seria microrganismo transgênico, o art. 18 da nova lei define:

“Art. 18 - Não são patenteáveis:

(...)

III - o todo ou parte dos seres vivos, exceto os microrganismos transgênicos que atendam aos três requisitos de patenteabilidade - novidade, atividade inventiva e aplicação industrial - previstos no art. $8^{\circ}$ e que não sejam mera descoberta.

Parágrafo único - Para os fins desta lei, microrganismos transgênicos são organismos, exceto o todo ou parte de plantas ou de animais, que expressem, mediante intervenção humana direta em sua composição genética, uma característica normalmente não alcançável pela espécie em condições naturais.” (grifonosso)

Até a aprovação deste texto, o tema gerou grandes controvérsias na comunidade científica nacional. Muitas eram as definições possíveis para microrganismos e afirmava-se que a ausência de uma definição apropriada poderia acarretar o patenteamento até mesmo do próprio homem, eis a razão de tantos elementos no inciso III do artigo 18. 
Para que se obtenha um título de proteção por patente é necessário que o objeto a ser protegido preencha dois requisitos. O primeiro, atividade inventiva, significa que não se trata de mera descoberta e sim de uma invenção. Invenção, conforme a lei, é tudo aquilo que não está compreendido pelo estado da técnica, que por sua vez é definido no art. $11, \S 1^{\circ}$, como "constituído por tudo aquilo tornado acessível ao público antes da data de depósito do pedido de patente, por descrição escrita ou oral, por uso ou qualquer outro meio, no Brasil ou no exterior”. Logo, seo pesquisador simplesmente identifica, isola um microrganismo que já existia na natureza, ele o está descobrindo; se altera geneticamente e chega a um novo ser, a um novo ser vivo, que não existia antes e que não viria a existir com a evolução natural das espécies, ele o está inventando.

Importante ressaltar que não pode ser patenteado o que foi tornado acessível ao público, “de forma escrita ou oral”; logo, se o pesquisador brasileiro publica um artigo detalhando seu novo microrganismo transgênico, não mais tem o direito sobre a patente; como publicação é quase uma obrigatoriedade para a ascensão acadêmica, caso o pesquisador pretenda obter a patente, é essencial que somente publique depois do depósito do pedido de proteção, prática comum na comunidade científica dos países desenvolvidos.

Além de ser uma “atividade inventiva”, deve ser passível de utilização em um processo industrial; logo, é preciso que a invenção tenha uma aplicação prática possível, a ser descrita no pedido de proteção. Deve estar inserido em um processo industrial específico, gerando um produto determinado.

Se o microrganismo é protegido por patente, lógico que se submete às regras da lei e, portanto, é desnecessária a reafirmação dos requisitos para a proteção no art. 18, inciso III.

A proibição do patenteamento de plantas e animais e do código genético está presente em diversos dispositivos, tanto no artigo 18, parágrafo único, transcrito acima, como no art. 10:

“Art. 10. Não se considera invenção, nem modelo de utilidade:

IX - o todo ou parte de seres vivos naturais e materiais biológicos encontrados na natureza, ou ainda que dela isolados, inclusive o genoma ou germoplasma de qualquer ser vivo natural e os processos biológicos naturais.”

Importa destacar que a proteção intelectual de microrganismos transgênicos, tal qual adotada pela Lei n. ${ }^{\circ}$ 9.279/96, já fora um compromisso adotado pelo Brasil, quando da ratificação do Acordo Geral de Tarifas e Comércio (GATT), em 1994, após a Rodada Uruguai. O GATT consiste em uma 
rodada multilateral de negociações com vistas à homogeneização das normas comerciais em todo o mundo e, na última rodada, conhecida como Rodada Uruguai, a propriedade intelectual foi um dos temas mais debatidos. Na ata final, foram fixados os Aspectos dos Direitos de Propriedade Intelectual Relacionados ao Comércio (Trade Related Intellectual Property Rights - TRIPs), ratificados pelo Brasil posteriormente.

\section{b.2. Legislação de proteção de cultivares}

Como visto acima, não se admite a proteção intelectual de plantas por meio de patentes; no entanto, o ordenamento jurídico posto prevê outra forma de proteção, sui generis, específica para o setor agrícola, conhecida como proteção de cultivares, direitos de melhorista, os plant breeders rights, como são conhecidos internacionalmente. No Brasil, foram admitidos a partir da lei $\mathrm{n}^{\circ}$ 9.456, de 25 de abril de 1997. Tal modalidade protetiva é sensivelmente distinta do sistema de patentes, tanto nos mecanismos de proteção, quanto nos direitos do titular, nos deveres dos concessionários, até mesmo com relação aos organismos gestores, que pertencem a Ministérios diversos.

Esta modalidade sui generis de propriedade intelectual foi criada inicialmente na Europa, para plantas, uma vez que se julgou que o sistema de patentes não era a forma mais apropriada para a proteção de variedades vegetais, pois suas características trariam mais complicações que benefícios para o setor agrícola como um todo. Com o passar dos anos, foi criada a União para a Proteção das Obtenções Vegetais (UPOV), entidade internacional autônoma que congrega os países que adotam esta modalidade de proteção somente Estados são admitidos - e que é vinculada à Organização Mundial de Propriedade Intelectual (OMPI), tendo inclusive sua sede no mesmo prédio da OMPI, em Genebra. Seu secretário-geral é a mesma pessoa que ocupa o posto de diretor geral da OMPI. A UPOV tem como principais funções a homogeneização legislativa internacional e o fomento das trocas de germoplasma e tecnologias entre as nações.

As duas últimas Convenções da UPOV datam de 1978 e 1991 e são muito distintas entre si, sendo que a última se aproxima do sistema de patentes, hoje aceito em poucos países de todo o mundo. A legislação brasileira está próxima da Convenção de 1991, mas com muitos caracteres positivos da Convenção de 1978. 
No cenário internacional, os seguintes países pertencem à UPOV:

\begin{tabular}{lclc} 
País & Convenção & País & Convenção \\
\hline Argentina & $1978^{*}$ & Israel & 1991 \\
Austrália & 1978 & Itália & 1991 \\
Áustria & 1978 & Japão & 1978 \\
Bélgica & 1991 & Países Baixos & 1991 \\
Canadá & 1991 & Nova Zelândia & 1991 \\
República Checa & $1978^{*}$ & Noruega & $1978^{*}$ \\
Dinamarca & 1991 & Polônia & 1978 \\
Finlândia & 1991 & Eslováquia & $1978^{*}$ \\
França & 1991 & África do Sul & 1991 \\
Alemanha & 1991 & Espanha & 1991 \\
Hungria & 1978 & Suécia & 1991 \\
Irlanda & 1991 & Suíça & 1991 \\
Uruguai & $1978^{*}$ & ReinoUnido & 1991 \\
Estados Unidos & 1991 & Paraguai & $1978^{*}$ \\
Portugal & $1978 *$ & Chile & $1978^{*}$ \\
Colômbia & $1978^{*}$ & Ucrânia & $1978^{*}$ \\
\hline
\end{tabular}

Fonte: UPOV, 15/03/1997.

(*) indicam os países que se tornaram membros da UPOV, sob a Convenção de 1978, após 1991.

Uma vez analisado o instituto de forma global, é possível estudar a proteção em si. Antes de tudo, porém, énecessário saber o que é cultivar; segundo o art. $3^{\circ}$, III da Lei 9.456/97, considera-se cultivar:

"a variedade de qualquer gênero ou espécie vegetal superior que seja claramente distinguível de outras cultivares conhecidas por margem mínima de descritores, por sua denominação própria, que seja homogênea e estável quanto aos descritores através de gerações sucessivas e seja de espécie passível de uso pelo complexo agroflorestal, descrita em publicação especializada disponível e acessível ao público, bem como a linhagem componente de híbridos;” (grifo nosso) 
Pela própria definição de cultivar, pode-se tirar diversos elementos necessários para a compreensão desta nova forma de modalidade de proteção intelectual de seres vivos. Os principais pontos novos são os sublinhados na citação e referem-se aos requisitos da proteção: distinguibilidade, denominação própria, homegeneidade e estabilidade. Para avaliar todos estes requisitos, o legislador estipulou a criação de descritores, que visam a identificar a planta. Assim, podem ser descritores a altura da planta, o número de folhas, a espécie botânica, sua resistência a uma determinada praga, enfim, inúmeras característica, de tal forma que o conjunto destas características seja suficiente para descrever uma cultivar específica.

Estes descritores são criados pelo Ministério da Agricultura, responsável pela administração dos registros de proteção; note-se que não se trata do Ministério da Indústria e Comércio, ao qual pertence o Instituto Nacional de Propriedade Intelectual, que administra as patentes. Prefere-se o Ministério da Agricultura para incentivar a proteção e melhor atender as necessidades do setor.

A planta deve ser claramente distinta das demais cultivares conhecidas, o que é verificado pelo seu conjunto de descritores. Assim, é essencial que a diferença com relação à cultivar de que se pede a proteção seja claramente distinta para evitar que se modifique alguma característica insignificante da planta e se obtenha a proteção. Estável é a planta que, "reproduzida em escala comercial, mantenha a sua homogeneidade através de gerações sucessivas”. Logo, se a produtividadeda planta cai rapidamente, como nos híbridos, a cultivar nãoéestável e, portanto, não pode ser protegida.

Homogeneidade é medida também com relação à produção da planta em escala comercial, exigindo-se que o conjunto de descritores que identificam a planta esteja presente em todas as cultivares. Se a cultivar não for homogênea não poderá ser protegida. É importante que tenha denominação correta, para evitar confusões no momento da busca de determinada cultivar ou mesmo na verificação dos demais requisitos. Deste modo, uma vez apresentada a cultivar para a proteção, fazem-se os testes de distinguibilidade, homogeneidade e estabilidade, conhecidos como testes de DHE.

O sistema de proteção de cultivares se aproxima do sistema de proteção por patentes, na medida em que garante o monopólio da comercialização do produto protegido ao titular da proteção. Mas as semelhanças terminam por aqui. De modo distinto do sistema de patentes, admite que se desenvolvam pesquisas a partir de uma variedade protegida, sem a autorização do seu titular; permite o uso de campos de replantio para formação de sementes pelo agricultor e isenta os pequenos agricultores do pagamento dos direitos de propriedade intelectual. Os 
prazos de proteção também são distintos; enquanto para patentes é de 20 anos, para cultivares os prazos são variáveis, sendo de quinze anos em geral, “excetuadas as videiras, as árvores frutíferas, as árvores florestais e as árvores ornamentais, inclusive, em cada caso, o seu porta-enxerto, para as quais a duração será de dezoito anos.” (art. 11).

Dentre as diferenças entre as duas modalidades de proteção, uma das principais, senão a mais importante, éa permissibilidade da criação de campos de replantio para a formação de sementes. Deve-se entender que no meio agrário existe uma prática milenar pela qual o agricultor separa os melhores frutos de sua produção e os utiliza como sementes para a próxima safra. Para tanto, planta algumas sementes em um terreno melhor, mais adubado, isolado do cultivo principal, com melhores condições de água e luz, garantindo a existência de grãos para o próximo plantio. Tal prática é responsável por mais de $80 \%$ da produção agrícola do Terceiro Mundo e sua proibição obrigaria a aquisição de sementes pelos agricultores e por conseqüência haveria uma forte elevação dos custos da produção agrícola, justamente em países onde a agricultura está em crise e sequer é suficiente para suprir as necessidades básicas de seus cidadãos.

No sistema de patentes, proíbe-se a formação dos campos de replantio para formação de sementes, pois ao replantar a semente o agricultor está reproduzindo um bem patenteado, ou melhor, o bem estará se reproduzindo naturalmente, mas com a ajuda do agricultor, o que por si constitui uma infração. Isto porque o sistema de patentes não foi criado para a proteção de seres vivos, mas sim para a proteção de máquinas, marcas e modelos de utilidade, que não se reproduzem. É por isso que se opta por modalidades sui generis de proteção, adotadas na maioria dos países que possuem alguma forma de legislação e permitida pelos TRIPS, na Rodada Uruguai do GATT.

\section{c) Regulamentação do acesso aos recursos genéticos brasileiros}

A partir da década de oitenta, com o início dos movimentos ecológicos, começou-se a dar a devida importância ao tema, principalmente com a conscientização do valor econômico dos recursos genéticos, em razão de sua aplicabilidade em diversos ramos industriais. A biodiversidade pode ser e é aplicada de inúmeras formas. Na agricultura, estima-se que os recursos genéticos de países de Terceiro Mundo foram responsáveis pelo aumento de cerca de 50\% dos cultivares nos Estados Unidos, o que representa cerca de US\$ 1 bilhão ao ano. Pode-se citar inúmeros exemplos, um deles, muito ilustrativo, seria o de duas espécies de tomates verdes silvestres encontradas no Peru no 
início dos anos 60 que, com seus gens, contribuíram de modo significativo para os processos de pigmentação de sólidos solúveis, acarretando lucros de aproximadamente US $\$ 5$ milhões por ano à indústria processadora de tomate ${ }^{10}$.

A indústria farmacêutica, que movimenta hoje cerca de US $\$ 170$ bilhões ao ano, é também grande usuária dos recursos genéticos dos países do Terceiro Mundo. Calcula-se que cerca de 30\% dos fármacos têm seus princípios ativos baseados em plantas ou microrganismos retirados sistematicamente da fauna e flora dos países subdesenvolvidos ${ }^{11}$. Tal proporção aumenta ao se considerar que a evolução da biotecnologia, como ciência, deu-se há poucos anos e, logo, os produtos biofarmacêuticos são os mais recentes, o que leva a concluir que a percentagem tende a subir consideravelmente. Importante ressaltar que o setor farmacêutico nacional é completamente dominado por multinacionais. As empresas brasileiras têm apenas um quarto do mercado interno e não são capazes de concorrer internacionalmente.

No setor da alimentação, os recursos genéticos, especialmente brasileiros, são responsáveis por uma proporção ainda maior dos produtos finais. Não em alimentos básicos, mas com relação aos alimentos industrializados. No setor de corantes naturais de produtos alimentícios, por exemplo, cerca de $85 \%$ da matéria-prima provêm do Brasil. Contudo, as empresas estrangeiras apenas retiram daqui as fontes destes corantes e os industrializam nos seus países de origem, principalmente Estados Unidos e Japão, não gerando empregos, divisas ou muito menos oferecendo qualquer contraprestação pelos produtos daqui retirados.

O governo brasileiro já se sensibilizou para a importância da regulamentação do acesso à biodiversidade e, há alguns anos, vem realizando esforços para viabilizar o uso racional e o desenvolvimento sustentável dos recursos genéticos. O evento mais importante realizado neste século, neste sentido, foi a Conferência do Rio de 1992 (ECO-92), na qual se firmaram diversos acordos no sentido de possibilitar a regulamentação do uso dos recursos genéticos do Terceiro Mundo em troca do acesso a tecnologias avançadas, visando assim uma melhor distribuição de riquezas entre as nações e diminuindo as diferenças norte-sul.

Desde então, alguns Estados já firmaram contratos com empresas privadas, como a Costa Rica, no exemplo Merck-InBio. Neste acordo trilateral, firmado pelo Governo da Costa Rica, pela InBio (ONG costarriquenha) e pela Merck (multinacional do setor farmacêutico), estabeleceu-se que a Organização não-governamental forneceria 10.000 espécies vegetais da flora deste país para pesquisas em novos produtos farmacêuticos e a Merck pagaria, além de 
uma parte dos royalties dos produtos obtidos, cerca de US\$1,135bilhão-cifra elevada se considerarmos que o PIB da Costa Rica foi de US\$ 5,2 bilhões em $1992^{12}$.

Outra iniciativa foi a do governo da Índia, onde estabeleceu-se ou reestabeleceu o conceito de direito de propriedadecoletiva. Nesta nova modalidade delegislação, o proprietário do direito sobre uma determinada espécie vegetal ou animal não é um pesquisador individual ou uma empresa, mas uma comunidade, sendo que os royalties devidos devem ser revertidos em prol desta comunidade. Na verdade, adaptaram-se os conceitos do direito ocidental relativo à propriedade intelectual aos conceitos orientais de propriedade sobre florestas, vegetações etc., que não são consideráveis de apropriação por indivíduos em si. Objetiva-se com a medida o desenvolvimento regional das áreas detentoras de biodiversidade ${ }^{13}$.

Deve-se destacar também a existência de normas regulatórias nos países do Pacto Andino, que já trataram do tema em nível supranacional. O mesmo problema já é entendido em todo o mundo como um importante mecanismo de desenvolvimento dos países do Terceiro Mundo.

No Brasil, inexiste regulamentação sobre a proteção do acesso aos recursos genéticos, sendo que se destaca o Projeto de Lei do Senado n ${ }^{\circ} 306$, um esboço para a regulamentação no país. O Projeto de Lei, na sua última versão, de 02 de junho de 1997, contém 60 artigos, inúmeros institutos jurídicosinéditos, mas com grandes falhas legislativas, o que o torna inaplicável no cenário jurídico nacional.

Nesse sentido, prevê-se a possibilidade de contratos de bioprospecção, para os casos em que empresas desejem pesquisar o material genético de determinada região, procurando potenciais fontes de produtos comerciais, como produtos farmacêuticos derivados de plantas, por exemplo. O prazo deste contrato é de um ano, não podendo ser renovável. Na verdade, trata-se mais de uma autorização do Poder Público que um contrato propriamente dito, pois há discricionariedade daAdministração em autorizar ou não a atividade. No entanto, não se fixa qual o organismo público responsável, se o Ibama, o Ministério da Ciência e Tecnologia, da Indústria e Comércio, do Meio Ambiente, Recursos Hídricos e Amazônia Legal ou outro.

O Projeto de Lei pretende também estabelecer que as comunidades locais “não permitam a retirada de material genético de seu território”, o que também constitui em complicado dispositivo. Como afinal fariam as comunidades para impedir que uma empresa transnacional ou mesmo uma empresa nacional retire ou não organismos vivos de sua região? A lei autoriza o uso da força? Se sim, até que ponto? Haveria uma mudança dos institutos criminais existentes, 
dos conceitos de uso arbitrário das próprias razões; seria uma defesa do patrimônio próprio, protegendo a floresta como quem protege sua propriedade privada, quando alguém invade a residência de um particular? Se não, a qual autoridade recorrer?

Também cria-se um contrato tripartite, com a presença do Estado, do pesquisador (pessoa física ou jurídica) e das comunidades locais, como uma determinada população ou população indígena. Nestes casos, prevê-se a repartição dos direitos de propriedade intelectual oriundos de produtos derivados das pesquisas realizadas com a participação de material genético brasileiro, ainda que não retirado do Brasil.

Como se vê, o Projeto de Lei 306, tal como se apresenta, é extremamente falho, gerando mais dúvidas que soluções, apesar de ser uma iniciativa louvável de seus autores, pois inexiste qualquer regulamentação sobre o assunto. Pode e deve ser aperfeiçoado para que não se torne mais uma norma ineficaz no ordenamento jurídicobrasileiro.

\section{Considerações finais}

Desde a ratificação da Agenda 21 e do Acordo Geral de Tarifas e Comércio, a legislação brasileira relativa à biodiversidade vem se alterando significativamente. Talvez nem se possa dizer alteração, pois não existiam normas regulatórias há mais de cinco anos, justo no país de maior diversidade biológica de todo o globo.

As principais normas referem-se à proteção intelectual, dando ensejo ao patenteamento de microrganismos transgênicos e à legislação de proteção de cultivares, uma forma sui generis de propriedade intelectual, para plantas; referem-se ainda à biossegurança, no tocante à segurança biológica, tanto em âmbitolaboratorial quanto para liberação de organismosgeneticamentemodificados no meio ambiente; referem-se, enfim, ao acesso à biodiversidade brasileira, um dos temas mais importantes ao se tratar do desenvolvimento sócio-econômico de países pobres, mas ricos em biodiversidade, no próximo século.

As normas brasileiras seguem os padrões internacionais e contam entre as mais avançadas do mundo no que toca à biossegurança. Infelizmente, quanto ao acesso aos recursos genéticos, o ponto mais importante para a amenização do subdensenvolvimento, grande problema deste país, inexiste legislação. 


\section{Notas}

1 CRUCIBLE GROUP. Gente, plantas y patentes. Impactos de la propiedad intelectual sobre la biodiversidad, el comercio y las sociedades rurales, p. 4.

2 Setores não formais seriam as comunidade indígenas e os curandeiros que detém conhecimentos farmacológicos, desconhecidos pelos governos e empresas.

3 MOONEY, Pat. Roy. O escândalo das sementes: o domínio na produção de alimentos, p. 3.

4 Em virtude do cientista Serguei Ivanovich Vavilov, que as identificou.

5 TACHINARDI, Maria Helena. A guerra das patentes, p. 95.

6 VARELLA, Marcelo Dias. Propriedade intelectual de setores emergentes: biotecnologia, fármacos e informática, pp. 40-43.

7 Contatos via internet.

8 VARELLA, M. D., op. cit., pp. 40-43 e 159.

9 TACHINARDI, op. cit., pp. 114-5 e 135.

10 CANHOS, Dora Ann Lange. Patentes em biotecnologia, p. 8.

11 Correa, Carlos M. "Indústria farmacéutica y biotecnologia. Oportunidades y desafios para los países en desarrolo”. México: Comércio Exterior. v. 4. nº. 11, nov. 92. p.1009.

12 Crucible Group, op. cit. pp. 81-2.

13 SHIVA, Vandana. Contatos verbais em abril de 1996, Brasília.

\section{Bibliografia}

CANHOS, Dora Ann Lange. Patentes em biotecnologia. São Paulo: Andre Tosello. 18 p.

CORREA, Carlos M. "Indústria farmacéutica y biotecnologia. Oportunidades y desafios para los países en desarrolo”. Comercio Exterior. v. 4. nº. 11, nov. 92.

CRUCIBLE GROUP. Gente, plantas y patentes. Impactos de la propiedad intelectual sobre la biodiversidad, el comercio y las sociedades rurales. Canadá: Centro Internacional de Investigaciones para el Desarrollo, 1995.

LAMPREIA, Luiz Felipe. Discurso de Ministro de Estado das Relações Exteriores, Embaixador Luiz Felipe Lampreia, na Comissão de Assuntos Econômicos do Senado Federal. Brasília: Senado Federal. 10/08/95.30 p.

MOONEY, Pat. Roy. O escândalo das sementes: o domínio na produção de alimentos. Rio de Janeiro: Nobel, 1987.

PALATNIK, Marcos. “Bioética”, in Seminário: biotecnologia: proteção e regulamentação. Rio de Janeiro: Fiocruz, 1995. 
TACHINARDI, Maria Helena. A guerra das patentes. Rio de Janeiro: Paz e Terra, 1993. VARELLA, Marcelo Dias. Propriedade intelectual de setores emergentes: biotecnologia, fármacos e informática. São Paulo: Atlas, 1996.

Resumo

Este artigo aponta os principais instrumentos jurídicos para a regulamentaçãodabiodiversidade, taiscomo: propriedadeintelectual, biossegurança e proteção do acesso aos recursos genéticos. São estudados de forma sucinta os principais fatores internacionais que conduziram o legislador brasileiro a adotar tais normas.

\section{Abstract}

This article points themain legal instruments of thebiodiversity regulation, like: intellectual property, biosafety and the protection of genetics resources. It studies the main international factors that have led the Brazilian lawmaker to adopt such rules.

Palavras-chave: Brazil. Biodiversidade. Propriedade intelectual. Biossegurança. Key-words: Brazil. Biodiversity. Intellectual property. Biosafety. 